Irena Pyka

Aleksandra Nocoń

Uniwersytet Ekonomiczny w Katowicach

\title{
Polityka makroostrożnościowa w Unii Europejskiej wobec instytucji ważnych systemowo
}

\author{
MACROPRUDENTIAL POLICY IN THE EUROPEAN \\ UNION AGAINST SYSTEMICALLY IMPORTANT \\ FINANCIAL INSTITUTIONS
}

\begin{abstract}
Polityka makroostrożnościowa wprowadzona regulacjami bazylejskimi po globalnym kryzysie finansowym ma charakter prewencyjny, chociaż obejmuje swym zakresem szereg rozwiazań instytucjonalnych $i$ instrumentalnych, stużacych zapobieganiu materializacji ryzyka systemowego. Analiza tych rozwiazań została powiazana $w$ opracowaniu z ich ukierunkowaniem na finansowe instytucje ważne systemowo (SIFIs), działajace w Unii Europejskiej. Wskazuje się w nim, że wprowadzone do polityki makroostrożnościowej rozwiazania instytucjonalne $i$ instrumentalne zwiększaja znacznie dyscyplinę regulacyjna $w$ systemie finansowym wspótczesnej gospodarki, nie zawsze natomiast sa przejrzyste, a ich skuteczność ograniczona, z uwagi na wtaściwości ryzyka systemowego. Rozproszenie regulacyjne obserwuje sie również $w$ Unii Europejskiej $w$ odniesieniu do finansowych instytucji ważnych systemowo. Wzmacnia ono argumenty na rzecz tezy o niskiej skuteczności polityki makroostrożnościowej $w$ dyscyplinowaniu stabilizujacej roli SIFIs w systemie finansowym gospodarki globalnej.
\end{abstract}

Słowa kluczowe: polityka makroostrożnościowa, instytucje ważne systemowo, bufory kapitałowe, MREL, TLAC

JEL Codes: G21, G28

\section{Wstęp}

Zainteresowanie polityką makrostrożnościową w publikacjach i pracach naukowych jest coraz większe, co wynika przede wszystkim z tego, że jest ona nowym obszarem stabilizowania systemu finansowego współczesnej gospodarki. Polityka makrostrożnościowa wymaga identyfikacji celów, towarzyszących jej założeń, rozpoznania instrumentów oddziaływania na system finansowy, czy identyfikacji konsekwencji, które powoduje w sferze realnej gospodarki. W opracowaniu podejmuje się problem oddziaływania polityki makroostrożnościowej na instytucje finansowe ważne systemowo. W okresie globalnego kryzysu finansowego okazały się one bowiem dobrym przewodnikiem ryzyka systemowego, co było powodem poddania ich po raz pierwszy szczególnym regulacjom ostrożnościowym. 
Zasadniczym celem opracowania jest ekspozycja problemów wynikających ze zmian konstytuujących odpowiedzialność za politykę makroostrożnościową w Unii Europejskiej, ze szczególnym uwzględnieniem jej oddziaływania na finansowe instytucje ważne systemowo. W opracowaniu wskazuje się, że wprowadzone do polityki makroostrożnościowej rozwiązania instytucjonalne i instrumentalne zwiększają znacznie dyscyplinę regulacyjną w systemie finansowym współczesnej gospodarki, nie zawsze natomiast są przejrzyste, a ich skuteczność ograniczona, z uwagi na właściwości ryzyka systemowego. Rozproszenie regulacyjne obserwuje sie również w Unii Europejskiej w odniesieniu do finansowych instytucji ważnych systemowo. Wzmacnia ono argumenty na rzecz tezy o niskiej skuteczności polityki makroostrożnościowej w dyscyplinowaniu stabilizującej roli SIFIs w systemie finansowym gospodarki globalnej.

Opracowanie zostało podzielone na trzy części w różnym stopniu $\mathrm{z}$ sobą korespondujące. W pierwszej analizuje się rozwiązania instytucjonalno-instrumentalne polityki makroostrożnościowej UE, wskazując główne obszary jej regulacyjnej niespójności. Druga część opracowania skupiona została na problemach powstających w związku z koniecznością identyfikacji instytucji ważnych systemowo. Treści trzeciej części opracowania dotyczą wyłącznie analizy instrumentów makroostrożnościowych, skierowanych na globalne i pozostałe instytucje ważne systemowo działające na terenie UE.

\section{Zakres polityki makroostrożnościowej w Unii Europejskiej}

Polityka makroostrożnościowa to pojęcie wprowadzone do nauki finansów pod wpływem doświadczeń globalnego kryzysu finansowego, który pokazał, że najbardziej rygorystyczne regulacje pojedynczych instytucji finansowych nie są wystarczającym warunkiem zachowania stabilności finansowej współczesnej gospodarki. Poważne zaburzenia międzynarodowego systemu finansowego obserwowane w tym czasie stały się bowiem istotną przyczyną załamania wzrostu gospodarczego i w efekcie obniżenia poziomu życia społeczeństwa globalnego. W tych okolicznościach uznano, że potrzebny jest nowy typ polityki gospodarczej państwa, wspomagający politykę monetarną i finansową (por. schemat 1).

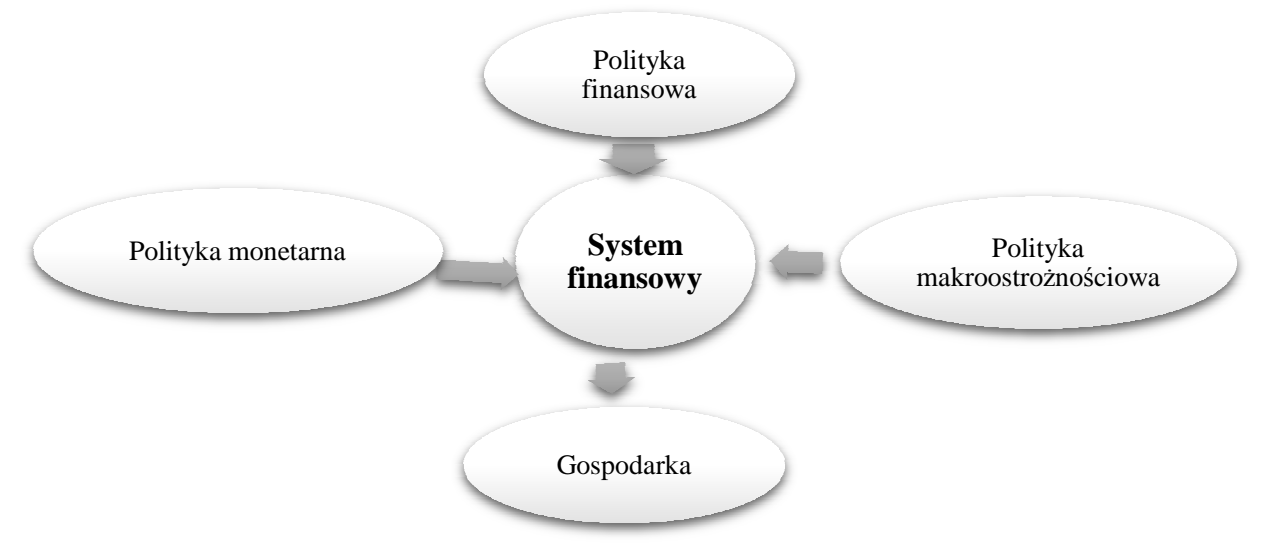

Schemat 1. Współczesne narzędzia makrostabilizacyjnej polityki gospodarczej Źródło: opracowanie własne. 
Polityka makroostrożnościowa, uzupełniając narzędzia polityki gospodarczej państwa, oparta została na zasadach ogólnych sformułowanych zarówno globalnie, jak i na poziomie Unii Europejskiej ${ }^{1}$. W Unii Europejskiej etap jej operacjonalizacji rozpoczął się w styczniu 2011 roku. Wtedy to bowiem powstaje zintegrowany Europejski System Nadzoru Finansowego. Nadzór makroostrożnościowy powierzono w nim nowo powołanej Europejskiej Radzie ds. Ryzyka Systemowego (ESRB). Celem jej działalności stała się odpowiedzialność za stabilność systemu finansowego jako całości, skierowana na ochronę gospodarki Unii Europejskiej przed znacznymi stratami w produkcie realnym ${ }^{2}$. ESRB powierzono też zadanie przeciwdziałania ryzykom systemowym, zagrażającym stabilności finansowej, czy ograniczanie ryzyk, które mogą wynikać zarówno z powiązań między instytucjami finansowymi i rynkami, jak też z uwarunkowań makroekonomicznych i strukturalnych. ESRB realizację tych zadań przeniosła na krajowe banki centralne strefy euro i Unii Europejskiej ${ }^{3}$, nie wykluczając z nich instytucji działających poza bankiem centralnym ${ }^{4}$. W tym jednak przypadku, koniecznością stała się ich ścisła współpraca $\mathrm{z}$ narodowymi bankami centralnymi ${ }^{5}$. Szczególna rola w nowych rozwiązaniach makroostrożnościowych przypadła EBC, który został zobligowany do wsparcia ESRB w różnych obszarach jej działalności makroostrożnościowej.

1 stycznia 2014 roku w UE zaczęły obowiązywać dwa ważne akty prawa europejskiego, zwane popularnie pakietem CRD IV/CRR ${ }^{6}$. Zawarte $w$ nich regulacje określiły instrumenty polityki makroostrożnościowej skierowane na ograniczenie ryzyka systemowego w państwach członkowskich Unii Europejskiej. Obok instrumentów o charakterze buforów kapitałowych wskazuje się w nich pozostałe instrumenty, które mogą być stosowane do celów polityki makroostrożnościowej. Ponadto, państwa członkowskie UE wraz z pojawieniem się pakietu CRD IV/CRR zobligowane zostały do wyznaczenia organu, odpowiedzialnego za stosowanie instrumentów makroostrożnościowych, wskazanie dodatkowych narzędzi makroostrożnościowych zasadnych w ograniczaniu ryzyka systemowego, a jeżeli będzie to niezbędne do przeprowadzenia procesu ich wdrażania. Pakiet CRD IV/CRR skonkretyzował też

\footnotetext{
1 International Monetary Fund: Key aspects of macroprudential policy. June 10, 2013. Retrieved: https://www.imf.org/external/np/pp/eng/2013/061013b.pdf. Dostęp: 15.04.2020; ESRB: Flagship Report on Macroprudential Policy in the Banking Sector. 2014.2 Retrieved: https://www.esrb.europa.eu/pub/pdf/other/140303_flagship_report.pdf. Dostęp: 15.04.2020; ESRB: Macroprudential policy beyond banking: an ESRB strategy paper. July 2016. Retrieved: https://www.esrb.europa.eu/pub/pdf/reports/20160718_strategy_paper_beyond_banking.en.pdf._ Dostęp: 15.04.2020.

${ }^{2}$ Rozporzadzenie Parlamentu Europejskiego i Rady (UE) nr 1092/2010 z dnia 24 listopada 2010 r. w sprawie unijnego nadzoru makroostrożnościowego nad systemem finansowym i ustanowienia Europejskiej Rady ds. Ryzyka Systemowego. Dz.Urz. UE L 331/1 z dnia 15.12.2010 r.

${ }^{3}$ M. Olszak: Zintegrowany nadzór finansowy a ryzyko instytucji finansowych. [W:] T. Czerwińska, K. Jajuga (red.), Ryzyko instytucji finansowych. Współczesne trendy i wyzwania. Wydawnictwo C.H. Beck, Warszawa 2016, s. 83.

${ }^{4}$ R. Herring, J. Carmassi: The structure of Cross-Sector Financial Supervision. Financial Markets, Institutions and Instruments, $\mathrm{nr}$ 1, 2008, s. 51-76.

5 A. Nocoń: System reagowania współczesnych banków centralnych na niestabilność sektora bankowego. Difin, Warszawa 2016, s. 156-157.

${ }^{6}$ A. Dobrzańska A.: Makroostrożnościowy wymiar regulacji CRDIV/CRR. Bezpieczny Bank 1(58), 2015, s. 13 .
} 
odpowiedzialność organów krajowych za politykę makroostrożnościową. Można więc przyjąć, że tym sposobem zamknął się proces budowania jej ram instytucjonalnych w Unii Europejskiej. Pakiet CRD IV/CRR wyposażył bowiem ostatecznie instytucje odpowiedzialne za politykę makroostrożnościową $\mathrm{W}$ narzędzia regulacyjne, których celem stała się reakcja na materializację ryzyka systemowego.

Przyjęcie zasad polityki makrostrożnościowej, a potem jej instytucjonalizacja i instrumentalizacja nie wyeliminowały jednak wątpliwości związanych ze skutecznością i efektywnością wprowadzonego do gospodarki nowego narzędzia regulowania stabilności system finansowego. Płaszczyzną dyskusji stały się teoretyczne przesłanki nadania jej charakteru systemowego. W pierwszej kolejności zrodziła sie wątpliwość dotycząca roli polityki makroostrożnościowej wobec polityki monetarnej, polityki finansowej państwa, a w konsekwencji także wobec polityki mikroostrożnościowej.

Odpowiedzialność za politykę makroostrożnościową powierzono bowiem bankom centralnym, które regulowały w rzeczywistości przedkryzysowej stabilność finansową poprzez kontrolę ogólnego poziomu cen. W kwestii tej sformułowano szereg zastrzeżeń, które pomimo powołania komitetów stabilności finansowej stale pozostają aktualne. Szereg wątpliwości dotyczy też niewyjaśnionych relacji pomiędzy polityką makrostrożnościową i finansową państwa. Ich koegzystentacja wymaga wyjaśnienia i zbudowania przejrzystości regulacyjnej w płaszczyźnie odpowiedzialności społecznej, jak też zadań powierzonych im w systemie finansowym. Uwagi badawczej wymaga też kazus o linię demarkacyjną między polityką makroostrożnościową a nadzorem makroostrożnościowym. Wydaje się, że problemy te wyznaczać będą w przyszłości kształt i zakres debaty o polityce makroostrożnościowej, jej celach, sposobach i metodach reagowania na materializację ryzyka systemowego. Zasadniczo jednak główny kierunek dyskusji o polityce makroostrożnościowej skoncentrowany został aktualnie na problemach nadzoru makroostrożnościowego. Utworzone bowiem w krajowych jurysdykcjach właściwe organy tego nadzoru określiły podstawy prawne odpowiedzialności instytucji sieci bezpieczeństwa finansowego za stabilność finansową. W Unii Europejskiej w oparciu o raport końcowy grupy de Larosière'a przedstawiony w dniu 25 lutego 2009 r. $^{7}$ zostały one zobowiązane do wzmocnienia europejskich rozwiązań w zakresie nadzoru, aby lepiej chronić obywateli i odbudować zaufanie do systemu finansowego ${ }^{8}$. Stąd też unijne instytucje nadzoru finansowego poddano reorganizacji i skierowano na realizację zadań związanych z nadzorowaniem ryzyka w systemie finansowym jako całości. Przyjęte rozwiązania nie tylko zwiększyły nacisk na nadzór makroostrożnościowy, ale zwiększyły też spójność między nadzorem makroi mikroostrożnościowym ${ }^{9}$. Uznano bowiem, że dla prawidłowego funkcjonowania Unii i globalnych systemów finansowych oraz ograniczenia czynników im zagrażających, wprowadzenie nadzoru makroostrożnościowego w żaden sposób nie umniejsza roli

\footnotetext{
${ }^{7}$ J. de Larosière (ed.): The high-level group on financial supervision in the EU. Report. Brussels, 25 February 2009.

${ }^{8}$ Rozporządzenie Parlamentu Europejskiego i Rady (UE) nr 1092/2010 z dnia 24 listopada 2010 r. w sprawie unijnego nadzoru makroostrożnościowego nad systemem finansowym i ustanowienia Europejskiej Rady ds. Ryzyka Systemowego. Dz.Urz. UE L 331/1 z dnia 15.12.2010 r.

${ }^{9}$ Ibidem.
} 
polityki mikroostrożnościowej ${ }^{10}$. W Unii Europejskiej w ślad za rozwiązaniami globalnymi powstał nowy ład regulacyjny. Opiera się on w pierwszej kolejności na redefinicji systemu kontroli ryzyka finansowego (por. schemat 2). W przestrzeni regulacyjnej pojawiło się ryzyko systemowe, zdefiniowane jako ryzyko zakłócenia systemu finansowego, które może wywołać poważne negatywne skutki dla rynku wewnętrznego i dla realnej gospodarki, którego źródła zakotwiczone są w strukturach wszystkich rodzajów pośredników finansowych i rynków finansowych ${ }^{11}$.

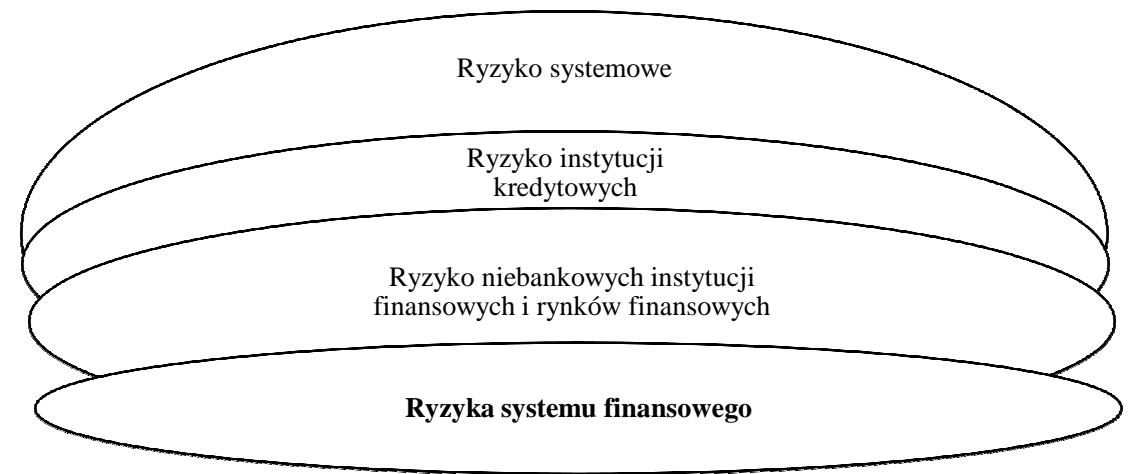

Schemat 2. Formy regulowanego ryzyka systemu finansowego Źródło: opracowanie własne.

W warunkach nowego ładu regulacyjnego rozszerzony został też zakres kontroli ryzyka instytucji kredytowych ${ }^{12}$. Kontrolę ryzyka wprowadzono też do instytucji ubezpieczeniowych i inwestycyjnych, w wyodrębnionych segmentach i transakcjach rynku finansowego. Redefinicja systemu kontroli ryzyka finansowego przeprowadzona więc została w płaszczyźnie pionowej i poziomej, nasilając w systemach finansowych dyscyplinę regulacyjną. Powstała modyfikacja jednocześnie zdywersyfikowała instytucjonalną odpowiedzialność za kontrolę ryzyka współczesnego systemu finansowego. Na szczeblu mikro pozostawiono bowiem analizę ryzyka generowanego przez pojedynczą instytucję finansową oraz jej odporność na niekorzystne zdarzenia. Pozostawiono też promowanie bezpiecznego działania instytucji i całego sektora finansowego. Dyscyplinę regulacyjną w tym zakresie powierzono dotychczasowym instytucjom nadzorczym w Unii Europejskiej. Nadzór makroostrożnościowy podporządkowano organom stabilności finansowej o rozwiązaniach przyjętych

${ }^{10}$ I. Pyka, A. Nocoń, J. Cichorska: Nowy ład regulacyjny w sektorze bankowym Unii Europejskiej. CeDeWu, Warszawa 2019, s. 89 i dalsze.

${ }^{11}$ Rozporządzenie Parlamentu Europejskiego i Rady (UE) nr 1092/2010 z dnia 24 listopada 2010 r. w sprawie unijnego nadzoru makroostrożnościowego nad systemem finansowym i ustanowienia Europejskiej Rady ds. Ryzyka Systemowego. Dz.Urz. UE L 331/1 z dnia 15.12.2010 r.

${ }^{12}$ Z. Darvas, D. Schoenmaker, N. Véron: Reforms to the European Union financial supervisory and regulatory architecture and their implications for Asia. ADBI Working Paper Series, No. 615, November 2016; G. L. Schiavo, A. Türk: The Institutional Architecture of EU Financial Regulation: The Case of the European Supervisory Authorities in the Aftermath of the European Crisis. [W:] L. Talani (eds.), Europe in Crisis. Palgrave Macmillan, London 2016, s. 89-121. 
w jurysdykcjach krajowych, a na szczeblu wszystkich państw członkowskich spięty ESRB - Europejską Radą ds. Ryzyka Systemowego (European Systemic Risk Board). Europejska Rada ds. Ryzyka Systemowego ma charakter kolegialny, z wiodącą rolą banków centralnych krajów UE (por. schemat 3).

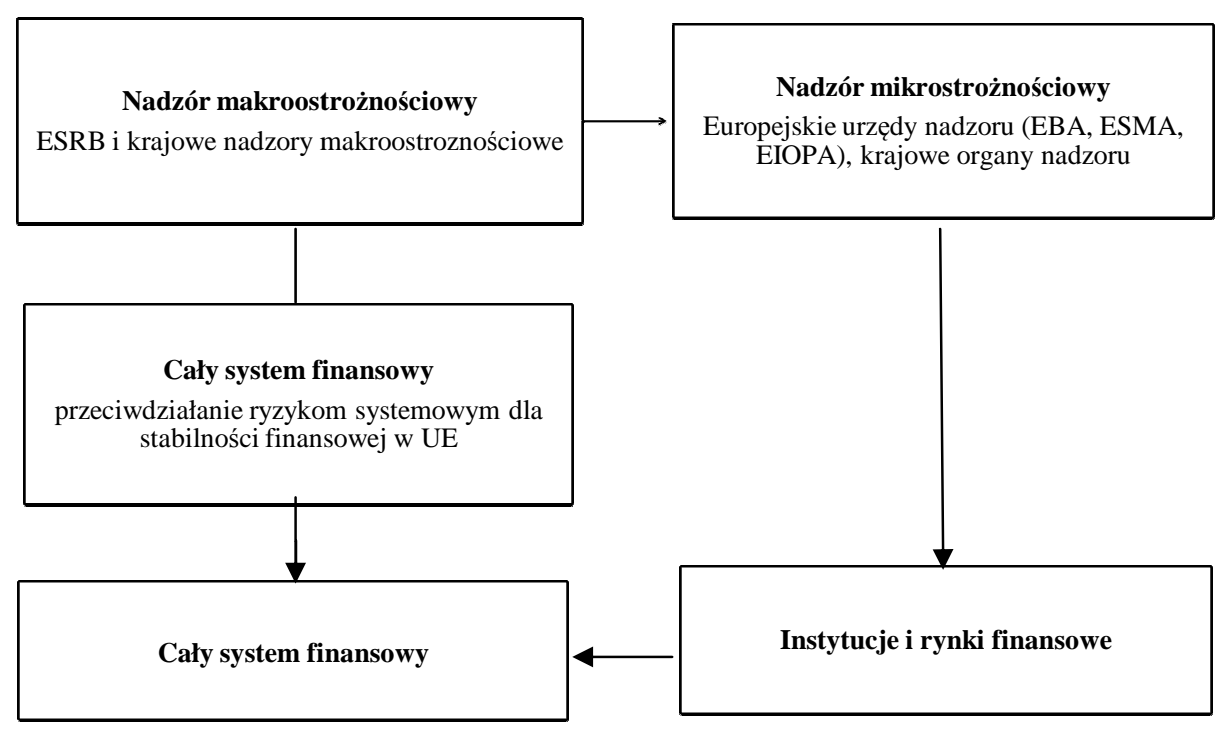

Schemat 3. Instytucje nadzoru finansowego w Unii Europejskiej Źródło: opracowanie własne.

Wprowadzone rozwiązania instytucjonalne są niehomogeniczne i mogą sprzyjać narastaniu napięć kompetencyjnych, szczególnie w sytuacji materializacji się jakiegokolwiek ryzyka destabilizującego system finansowy. Odpowiedzialność za politykę makroostrożnościową jest bowiem wielopłaszczyznowa i prowadzona przez organa na różnych poziomach zarządzania kryzysowego. Mechanizm identyfikowania ryzyk makroostrożnościowych ma charakter wielokierunkowy i osłabia sprawność wykorzystania instrumentów monitorujących, jak też ograniczających ryzyko systemowe.

Problematyczne wydają się również przyjęte rozwiązania w zakresie instrumentów nadzoru makroostrożnościowego (por. schemat 4). Sprzyjają one wzajemnemu przenikaniu się mikro i makro norm ostrożnościowych, osłabiając przejrzystość regulacyjną systemu finansowego Unii Europejskiej. Kontrowersje dotyczą także nierównomiernego rozkładu obciążeń kosztami unijnych regulacji instytucji finansowych, co ma istotne znaczenie, zważywszy na skomplikowany system finansowy Unii Europejskiej. Stanowi on, jak wiadomo zbiór instytucji finansowych o różnej tradycji, historii rozwoju, strukturze wewnętrznej, rozmiarach czy kondycji finansowej. Stąd też rozmiary generowanego w nich ryzyka systemowego są zróżnicowane, a koszty jednorodne. 


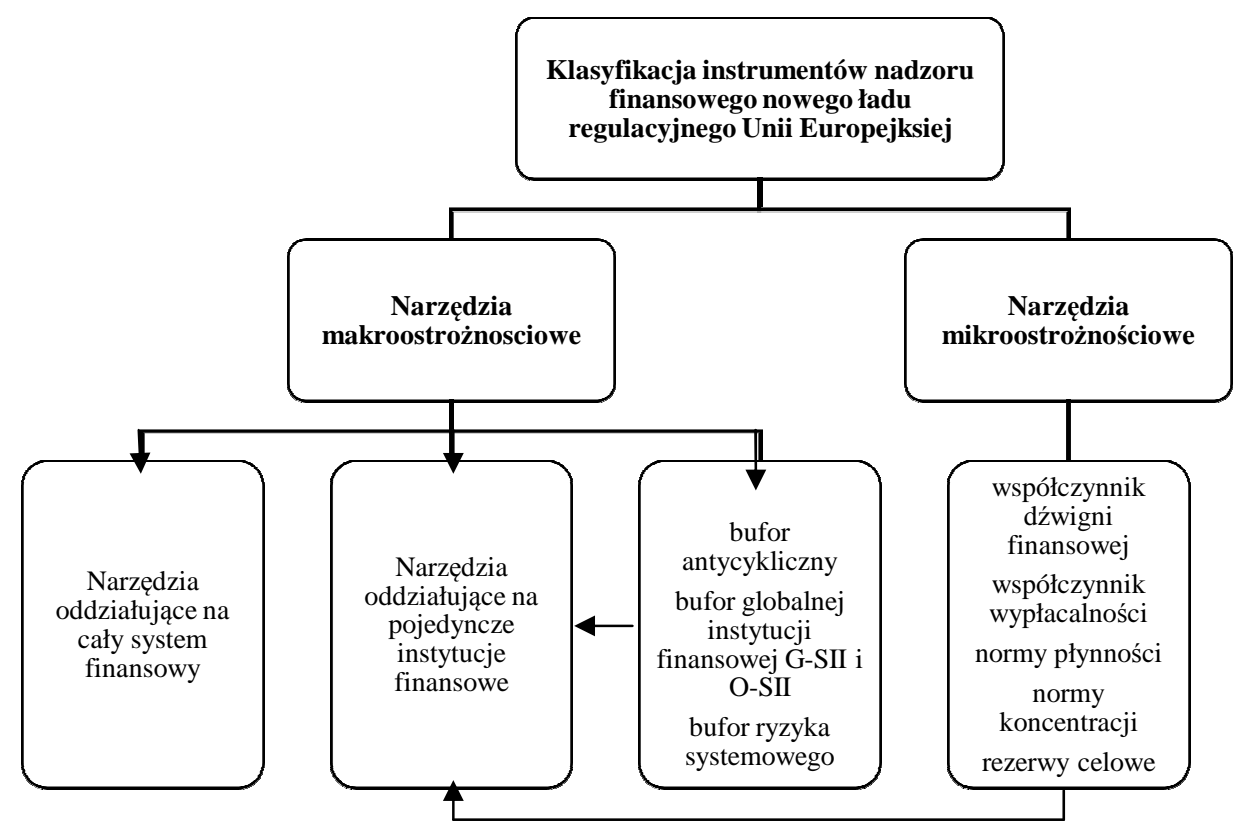

Schemat 4. Instrumenty nadzoru finansowego w Unii Europejskiej Źródło: opracowanie własne.

Jednocześnie zauważa się, że instrumenty polityki makroostrożnościowej, stanowiące narzędzia reakcji na zidentyfikowane ryzyko systemowe, nie stanowią listy zamkniętej, a ich działanie mogą być modyfikowane ${ }^{13}$.

\section{Rodowód finansowych instytucji ważnych systemowo w Unii Europejskiej}

Powstanie finansowych instytucji ważnych systemowo pozostaje w ścisłej korelacji z pojawieniem się w gospodarce globalnej podmiotów "too big to fail" (TBTF), a zatem takich, które są tak duże, że nie mogą upaść. Społeczne koszty ich upadku, jak wynika z różnych szacunków, są bowiem zazwyczaj wyższe niż środki finansowe przeznaczane na ich ratowanie ${ }^{14}$. Intensywny rozwój TBTF związany był $\mathrm{z}$ dotychczas szybko postępującą liberalizacją przepływów pieniężnych i kapitałowych w gospodarce światowej. Dlatego też podmioty "too big to fail" funkcjonują głównie w krajach wysokorozwiniętych, wśród których znajdują się też silne gospodarczo państwa strefy euro. W Unii Europejskiej rozwój finansowych instytucji ważnych systemowo otrzymał

\footnotetext{
${ }^{13}$ P. Bańbuła: Polityka makroostrożnościowa: przesłanki, cele, instrumenty i wyzwania. Materiały i Studia, nr 298, NBP, Warszawa 2013, s. 73.

${ }^{14}$ J. H. Boyd, A. Heitz: The Social Costs and Benefits of Too-Big-To-Fail Banks: A "Bounding" Exercise. Journal of Banking \& Finance, No. 68, 2016, s. 251-265.
} 
nowy impuls wraz z przyjęciem do niej po roku 2004 nowych państw członkowskich. Rozpoczął się bowiem wtedy okres ekspansji kapitałowej wysokorozwiniętych krajów UE do państw Europy Środkowo-Wschodniej. Państwa EŚW chętnie ten kapitał przyjmowały. Nie posiadały bowiem często własnych zasobów kapitałowych, niezbędnych do przeprowadzenia prywatyzacji majątku państwowego. Jednocześnie rozwinięte kraje UE $\mathrm{w}$ ten sposób zdobywały nowe rynki, czy intratne źródła powiększania swoich dochodów. Do globalnego kryzysu finansowego istniały więc korzystne warunki ekspansji TBTF ( "too big to fail”). Dopiero po globalnym kryzysie finansowym instytucje te uznano za nośniki ryzyka systemowego, poddając ściślejszej kontroli i regulacjom ostrożnościowym.

W 2011 roku Bazylejski Komitet ds. Nadzoru Bankowego, negatywnie opiniując udział TBTF w globalnym kryzysie finansowym, przedstawił metodologię wyodrębnienia spośród nich finansowych instytucji ważnych systemowo (SIFs) ${ }^{15}$. Okazało się bowiem, że o ile każda instytucja TBTF jest instytucją ważną systemowo, to nie każda instytucja ważna systemowo jest TBTF-em. Zadania związane z identyfikacją instytucji ważnych systemowo powierzono Radzie Stabilności Finansowej (FSB). Począwszy od 2011 roku FSB publikuje w listopadzie każdorazowo ich nową listę. Instytucje te zwane są globalnymi instytucjami finansowymi - G-SIBs (Global Systematically Important Banks). W gospodarce światowej mogą występować jednak inne instytucje finansowe ważne systemowo. Nie są identyfikowane przez FSB i klasyfikowane na podstawie odrębnych kryteriów ${ }^{16}$.

Tabela 1. Grupy bankowe i samodzielne banki o statusie istotnych i mniej istotnych po rocznej ocenie przeprowadzonej w $2018 \mathrm{r}$.

\begin{tabular}{|c|c|c|c|}
\hline \multirow[b]{2}{*}{ Wyszczególnienie } & \multirow{2}{*}{$\begin{array}{l}\text { Suma aktywów } \\
\text { (mld euro) }\end{array}$} & \multicolumn{2}{|c|}{ Liczba podmiotów } \\
\hline & & $\begin{array}{c}\text { Na poziomie } \\
\text { skonsolidowanym }\end{array}$ & $\begin{array}{c}\text { Na poziomie } \\
\text { jednostkowym }\end{array}$ \\
\hline Instytucje istotne & 21399,7 & 119 & 822 \\
\hline Instytucje mniej istotne & 4919,7 & 2719 & 3008 \\
\hline Razem & 26319,4 & 2838 & 3830 \\
\hline
\end{tabular}

Źródło: opracowanie własne na podstawie danych EBC.

${ }^{15}$ Basel Committee on Banking Supervision: Global systemically important banks: assessment methodology and the additional loss absorbency requirement. Bank for International Settlements, November 2011.

${ }^{16}$ Liczba tych instytucji ważnych systemowo w Unii Europejskiej jest zmienna. Zmiany na liście banków nadzorowanych przez EBC dokonywane w ciagu roku wynikaja z reorganizacji grup, fuzji i przejecć, udzielenia nowych zezwoleń lub wycofania licencji. W 2018 r. z listy usunięto pięć banków: Banco Mare Nostrum, S.A. przejęła Bankia S.A.; Nordea Bank AB (publ), Suomen sivuliike (fiński oddział Nordei) przestał być odrębnym podmiotem, gdy jego spółka dominująca Nordea Bank AB (publ) połączyła się z Nordea Bankiem Abp; Danske Bank Plc (fińska spółka zależna Danske Banku A/S) przeniósł swoją działalność do spółki dominującej i przestał istnieć; VTB Bank (Austria) AG przestał istnieć po przeniesieniu działalności do niemieckiego VTB Banku (Europe) S.E., nadzorowanego jako instytucja mniej istotna; licencja bankowa Cyprus Cooperative Banku Ltd została cofnięta przez EBC. Cztery banki zostały objęte bezpośrednim nadzorem EBC: w wyniku utworzenia grupy Luminor do listy instytucji istotnych dodano Luminor Bank AS z Estonii i Luminor Bank AS z Łotwy; Banque Internationale à Luxembourg S.A. przeszedł pod bezpośredni nadzór EBC po odłączeniu się od Precision Capital S.A. [źródło: EBC: Raport roczny EBC z działalności nadzorczej 2018. Retrieved: https://www.bankingsupervision.europa.eu/press/publications/annualreport/html/ssm.ar2018 927cb99de4.pl.html\#toc1. Dostęp: 15.04.2020]. 
W Unii Europejskiej metody identyfikowania globalnych instytucji o znaczeniu systemowym zostały zawarte w dyrektywie CRD IV. Wskazuje się w niej, że globalną instytucją finansową o znaczeniu systemowym może być wyłącznie unijna instytucja dominująca. Nie jest nią natomiast instytucja zależna od unijnej instytucji dominującej. Przyjęta interpretacja powoduje, że instytucja ważna systemowo jest identyfikowana w kraju, w którym mieści się siedziba unijnej instytucji dominującej, a nie w kraju siedziby jej podmiotu zależnego. W myśl przyjętych założeń globalne instytucje finansowe UE zostały podzielone na pięć podkategorii, zróżnicowanych pod względem generowanego ryzyka systemowego. Każdej $\mathrm{z}$ nich przypisano konieczność utrzymywania dodatkowego wymogu kapitałowego w wysokości od $1 \%$ do 3,5\% sumy ekspozycji ważonych ryzykiem. Dyrektywa CRD IV zakłada natomiast konieczność przeprowadzania corocznego przeglądu globalnych instytucji o znaczeniu systemowym oraz wymaga podawania do publicznej wiadomości informacji o zakwalifikowaniu danej instytucji do określonej podkategorii. Uznaje się bowiem, że instytucje ważne systemowo mogą stosować różne strategie swej działalności operacyjnej, zmieniając w czasie swą pozycję względem ryzyka systemowego. W dyrektywie CRD IV formułuje się także szereg specyficznych zapisów w odniesieniu do instytucji o znaczeniu systemowym innych niż globalne. Władze krajowe zobligowane zostały też raz w roku dokonywać przeglądu i aktualizacji listy O-SII. Ostatecznie więc wszystkie instytucje ważne systemowo w Unii Europejskiej dzielą się na globalne instytucje o znaczeniu systemowym, określane symbolem G-SII oraz inne instytucje o znaczeniu systemowym, określane symbolem O-SII. Ich standardy techniczne oraz definiowanie poszczególnych podkategorii zawiera Rozporządzenie Komisji (UE) nr 1222/2014 z dnia 8 października

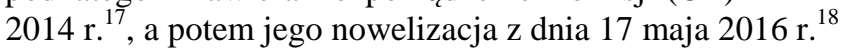

Identyfikacja unijnych instytucji ważnych systemowo przyczyniła się też do rozbudowania ich bazy instytucjonalnej i objęcia nadzorem finansowym. Wszystkie zadania związane $\mathrm{z}$ identyfikacją instytucji ważnych systemowo powierzono Europejskiemu Urzędowi Nadzoru Bankowego (EBA). Państwa członkowskie UE na terenie swoich jurysdykcji zostały jednak zobligowane do wskazania organu odpowiedzialnego za identyfikację globalnych i innych instytucji o znaczeniu systemowym. Może nim być organ odpowiedzialny za nadzór (competent authority) lub inny wyznaczony organ (designated authority) $\mathrm{z}$ danego kraju członkowskiego. Identyfikacja innych instytucji o znaczeniu systemowym (O-SII) dokonuje się więc na poziomie indywidualnym, sub-skonsolidowanym lub skonsolidowanym w oparciu o następujące kryteria ${ }^{19,20}$ :

\footnotetext{
17 Rozporządzenie delegowane Komisji (UE) nr 1222/2014 z dnia 8 października 2014 r. uzupełniające dyrektywę Parlamentu Europejskiego i Rady 2013/36/UE w odniesieniu do regulacyjnych standardów technicznych dotyczących określenia metody identyfikacji globalnych instytucji o znaczeniu systemowym oraz definiowania podkategorii globalnych instytucji o znaczeniu systemowym. Dz. Urz. UE L $330 / 27$ z dnia 15.11.2014 r.

${ }^{18}$ Rozporządzenie delegowane Komisji (UE) 2016/1608 z dnia 17 maja 2016 r. zmieniające rozporządzenie delegowane (UE) nr 1222/2014 w odniesieniu do regulacyjnych standardów technicznych dotyczących określenia metody identyfikacji globalnych instytucji o znaczeniu systemowym oraz definiowania podkategorii globalnych instytucji o znaczeniu systemowym (tekst mający znaczenie dla EOG). Dz.Urz. UE nr L 240/1.

${ }^{19}$ Dyrektywa Parlamentu Europejskiego i Rady 2013/36/UE z dnia 26 czerwca 2013 r. w sprawie warunków dopuszczenia instytucji kredytowych do działalności oraz nadzoru ostrożnościowego nad instytucjami kredytowymi i firmami inwestycyjnymi, zmieniającą dyrektywę 2002/87/WE i uchylająca dyrektywy
} 
1. wielkość instytucji,

2. znaczenie dla gospodarki UE lub danego państwa członkowskiego,

3. znaczenie w działalności transgranicznej,

4. wzajemne powiązania danej instytucji lub grupy $\mathrm{z}$ systemem finansowym ${ }^{21}$.

\section{Instrumenty nadzoru makroostrożnościowego wobec instytucji ważnych systemowo w Unii Europejskiej}

Zasadniczo instrumentów polityki makroostrożnościowej, regulujących działalność instytucji ważnych systemowo, jest niewiele (por. schemat 5). Bezpośrednio związane są one z tzw. buforami kapitałowymi. Bufory te pojawiły się w przestrzeni regulacyjnej w celu zapewnienia instytucjom nadzoru makroostrożnościowego uprawnień do radzenia sobie z upadkiem instytucji finansowej. Bufor kapitałowy reprezentuje bowiem zapas środków pieniężnych zakumulowany w celu zachowania stabilności i bezpieczeństwa instytucji finansowej. W ramach dotychczas obowiązujących regulacji makroostrożnościowych bufory kapitałowe ściśle określono. Instytucje ważne systemowo w Unii Europejskiej muszą respektować bufor globalnej instytucji finansowej o znaczeniu systemowym G-SII, ale też bufor innej instytucji finansowej o znaczeniu systemowym G-OII. Zgodnie z prawem unijnym nakładanie tych buforów odbywa się w dwóch etapach. Pierwszy obejmuje wyznaczenie instytucji ważnych systemowo. Drugi sprowadza się do nałożenia bufora kapitałowego. Najpierw więc musi być przygotowana lista instytucji, do których bufory się odnoszą. Wysokość bufora G-SII zależy od kategorii, do której instytucja została przypisana. Minimalna wartość bufora dla najniższej z pięciu kategorii wynosi $1 \%$, każda kolejna kategoria zwiększa bufor o $0,5 \%$, zatem maksymalna wartość dodatkowego wymaganego kapitału to 3,5\%. Wysokość bufora dla innych instytucji o znaczeniu systemowym ustala właściwy organ na maksymalnym poziomie $2 \%$, pozostawiając swobodę narodową w zakresie jego rozkładu względem poszczególnych instytucji. Nie może on jednak powodować nieproporcjonalnych i nadmiernie niekorzystnych efektów dla systemu finansowego kraju członkowskiego lub całej UE. Wysokość tego bufora podlega więc przeglądowi co najmniej raz w roku ${ }^{22}$.

2006/48/WE oraz 2006/49/WE. (OJ L176) - Capital Requirements Directive IV, CRD IV, art. 131 ust. 5 CRD IV; I. Pyka, A. Nocoń, J. Cichorska: Nowy ład regulacyjny w Unii Europejskiej, op. cit., s. 121.

${ }^{20}$ Aktualizowana każdego roku lista innych instytucji o znaczeniu systemowym w UE dostępna jest na stronie Europejskiego Urzędu Nadzoru Bankowego: https://eba.europa.eu/risk-analysis-and-data/other-systemicallyimportant-institutions-o-siis-

${ }_{21}$ W Polsce Komisja Nadzoru Finansowego opracowała szczegółowe krajowe kryteria klasyfikowania instytucji jako innych instytucji o znaczeniu systemowym (O-SII) w dokumencie pt: „Skrócony opis metod stużacych ocenie nadzorczej przy identyfikacji innych instytucji o znaczeniu systemowym”, https://www.knf.gov.pl/knf/pl/komponenty/img/Skrocony_opis_metod_sluzacych_ocenie_nadzorczej_przy_id entyfikacji_innych_instytucji_o_znaczeniu_systemowym.pdf.

${ }^{22}$ Dyrektywa Parlamentu Europejskiego i Rady 2013/36/UE z dnia 26 czerwca 2013 r. w sprawie warunków dopuszczenia instytucji kredytowych do działalności oraz nadzoru ostrożnościowego nad instytucjami kredytowymi i firmami inwestycyjnymi, zmieniającą dyrektywę 2002/87/WE i uchylająca dyrektywy 2006/48/WE oraz 2006/49/WE. (OJ L176) - Capital Requirements Directive IV, CRD IV, art. 131 ust. 5 CRD IV oraz Rozporządzenie delegowane Komisji (UE) 2016/1608 z dnia 17 maja 2016 r. zmieniające rozporządzenie delegowane (UE) nr 1222/2014 w odniesieniu do regulacyjnych standardów technicznych dotyczących określenia metody identyfikacji globalnych instytucji o znaczeniu systemowym oraz definiowania 


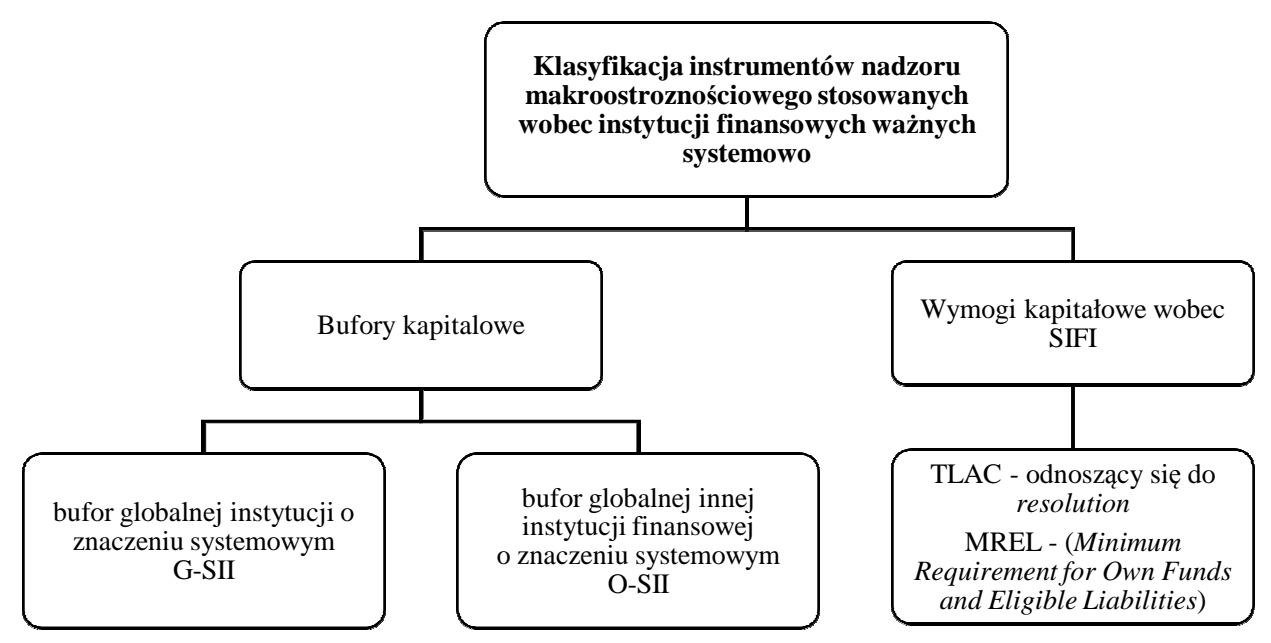

Schemat 5. Instrumenty nadzoru makroostrożnościowego wobec instytucji finansowych ważnych systemowo w Unii Europejskiej

Źródło: opracowanie własne.

Drugą grupę instrumentów, regulujących działalność instytucji ważnych systemowo, stanowią formułowane wobec nich wymogi kapitałowe. Organa regulacyjne zaczęły dopiero po czasie wyznaczać poziom absorpcji strat, których potrzebowały SIFI, w celu ograniczenia potencjalnego wpływu ryzyka systemowego na ich bezpieczeństwo finansowe. W 2010 roku Rada Stabilności Finansowej (FSB) wystosowała pierwsze zalecenia do banków o globalnym znaczeniu systemowym (G-SIB) do większej absorpcji strat. W 2013 roku przywódcy G-20 poparli ten projekt. W listopadzie 2014 roku FSB rozpoczęła konsultacje w sprawie wniosku wspólnego międzynarodowego standardu dotyczącego zdolności do całkowitego pokrywania strat przez G-SIB. Dokument ten - powszechnie rozpoznawany jako TLAC - zakłada, że straty te powinny być pokrywane z funduszy własnych lub długu przeznaczonego na konwersję na kapitał na pokrycie strat i dokapitalizowanie banku. W listopadzie 2015 roku FSB opublikował ostateczny standard TLAC, a Bazylejski Komitet Nadzoru Bankowego dokument konsultacyjny $w$ tej sprawie. Ostatecznie TLAC został zatwierdzony dopiero w październiku 2016 roku. TLAC (Total Loss-Absorbing Capacity) obejmuje wszystkie instytucje na świecie, zaklasyfikowane do kategorii ważnych systemowo. TLAC określa dodatkowe wymogi ostrożnościowe dla finansowych instytucji ważnych systemowo, czyli dla 30 największych globalnych G-SIBs (Global Systemically Important Banks) ${ }^{23}$, uznanych za instytucje bardziej narażone na ryzyko systemowe niż mniejsze jednostki. Celem TLAC jest zwiększenie możliwości ich rekapitalizacji w sytuacji uporządkowanej restrukturyzacji i likwidacji (resolution). TLAC jest wprowadzony do systemu finansowego w dwóch etapach. Pierwszy dotyczy stycznia 2019 r. Drugi etap powinien

podkategorii globalnych instytucji o znaczeniu systemowym (tekst mający znaczenie dla EOG). Dz.Urz. UE nr L 240/1.

${ }^{23}$ Ponieważ regulacja TLAC obejmuje instytucje finansowe na całym świecie, nie tylko w UE, przyjmuje się nomenklaturę uniwersalną i słowo „bank” oraz G-SIB, a nie jak w przypadku UE ,instytucja kredytowa” i GSII. 
mieć miejsce w roku 2022. Zasadniczo na TLAC w całości składają się fundusze własne i zobowiązania podporządkowane, które $\mathrm{w}$ wiarygodny sposób kwalifikują się do umorzenia lub konwersji długu.

MREL opracowany został przez Europejski Urząd Nadzoru Bankowego (EBA) dla instytucji finansowych Unii Europejskiej ${ }^{24}$. 23 listopada 2016 Komisja Europejska zaproponowała zmiany do CRD i BRRD ${ }^{25}$, w celu wdrożenia w systemie unijnym wymogów TLAC, jednocześnie dokonując zmiany systemu TLAC. Regulacja MREL weszła bowiem w życie w państwach UE między lipcem a wrześniem 2016, wyprzedzając regulacje TLAC. EUNB opublikował końcowy raport MREL (Minimum Requirement for Own Funds and Eligible Liabilities) i zaimplementował go po wprowadzeniu w nim stosownych zmian - do prawodawstwa Wspólnoty 14 grudnia 2016 roku. MREL jest regulacją obejmującą wszystkie kraje Unii Europejskiej od 2017 roku. MREL również określa minimalny poziom kapitału własnego i kwalifikowanych zobowiązań, które w sytuacji uporządkowanej likwidacji instytucji kredytowej (resolution) mają być przeznaczone na pokrycie strat i zapewnić, że straty będą pokryte przez kapitał akcjonariuszy oraz wierzycieli, a nie z pieniędzy podatników.

Z założenia standardy TLAC i MREL dla G-SIBs z siedzibą w Unii Europejskiej powinny się uzupełniać, niemniej jednak są obszary, w których przyjmują one różne rozwiązania (por. tabela 2). Wymogi MREL dotyczą bowiem wszystkich instytucji ważnych systemowo UE bez względu na ich wielkość. TLAC natomiast dotyczy 30 największych SIBs z całego świata. MREL stanowi standard UE dla kapitału uporządkowanej likwidacji banków „bail-in", wprowadzonego w pakiecie BRRD/SRMR z 2014 r. który będzie wdrażany do $2023 \mathrm{r}^{26}$

\footnotetext{
${ }^{24}$ European Banking Authority: Consultation Paper. Draft Regulatory Technical Standards on criteria for determining the minimum requirement for own funds and eligible liabilities under Directive 2014/59/EU. 28 November 2014, EBA/CP/2014/41.

${ }_{25} \mathrm{Na}$ poziomie UE dyrektywa w sprawie naprawy i restrukturyzacji i uporządkowanej likwidacji banków (BRRD) określa również ramy dla wszystkich europejskich banków i firm inwestycyjnych (nie tylko G-SIB), w celu spełnienia minimalnego wymogu w zakresie funduszy własnych i zobowiązań kwalifikowalnych (MREL). Chociaż parametry, zakres i wymagania TLAC i MREL różnią się na wiele sposobów, oba mają na celu zapewnienie bankom wystarczających zasobów na pokrycie strat i zaspokojenia potrzeb w zakresie dokapitalizowania $w$ ramach rezolucji. Krajowe organy ds. restrukturyzacji i uporządkowanej likwidacji lub (w odniesieniu do niektórych banków strefy euro) Jednolita Rada ds. Restrukturyzacji i Uporządkowanej Likwidacji ustali poziomy MREL dla poszczególnych banków i firm inwestycyjnych, na podstawie kryteriów oceny określonych w regulacyjnych standardach technicznych (RTS), przyjętych na podstawie BRRD. W listopadzie 2016 r. Komisja Europejska zaproponowała zmiany do unijnego rozporządzenia w sprawie wymogów kapitałowych (CRR), w celu ustanowienia zharmonizowanych wymogów TLAC dla unijnych G-SIB. Jednocześnie Komisja zaproponowała zmiany do BRRD i rozporządzenia w sprawie jednolitego mechanizmu restrukturyzacji i uporządkowanej likwidacji (SRM), w celu dostosowania wymogów MREL do standardu TLAC, w tym propozycji zrewidowanych rankingów niewypłacalności, aby pomóc bankom w spełnieniu wymogów podporządkowania w zakresie kwalifikowalności TLAC

${ }^{26}$ Rozporządzenie delegowane Komisji (UE) nr 1222/2014 z dnia 8 października 2014 r. uzupełniające dyrektywę Parlamentu Europejskiego i Rady 2013/36/UE w odniesieniu do regulacyjnych standardów technicznych dotyczących określenia metody identyfikacji globalnych instytucji o znaczeniu systemowym oraz definiowania podkategorii globalnych instytucji o znaczeniu systemowym. Dz. Urz. UE L 330/27 z dnia 15.11.2014 r.
} 
Tabela 2. Porównanie TLAC i MREL

\begin{tabular}{|c|c|c|}
\hline Wyszczególnienie & TLAC & MREL \\
\hline Zakres & G-SIB & Banki i firmy inwestycyjne z UE \\
\hline $\begin{array}{c}\text { Poziom } \\
\text { zastosowania }\end{array}$ & $\begin{array}{c}\text { Podmioty restrukturyzacji } \\
\text { i uporządkowanej likwidacji } \\
\text { (zewnętrzny TLAC) } \\
\text { Istotne podgrupy (wewnętrzny TLAC) }\end{array}$ & $\begin{array}{l}\text { Wymagania indywidualne } \\
\text { i skonsolidowane }\end{array}$ \\
\hline Minimalny poziom & Filar 1 & Podejście filarowe 2 (ale kryteria EBA) \\
\hline Mianownik & RWA i mianownik wskaźnika dźwigni & $\begin{array}{c}\text { Fundusze własne + zobowiązania } \\
\text { ogółem }\end{array}$ \\
\hline $\begin{array}{c}\text { Kwalifikujace sie } \\
\text { zobowiazania }\end{array}$ & Wąska kategoria & Szersze, różne rodzaje długów \\
\hline Podporzadkowanie & Obowiązkowe (ograniczone wyłączenia) & $\begin{array}{c}\text { Nieobowiązkowe } \\
\text { (ale mogą być wymagane) }\end{array}$ \\
\hline Minimalny dtug & Tak (oczekiwanie 33\%) & Nie \\
\hline
\end{tabular}

Źródło: opracowanie własne.

Wymóg MREL kieruje się zasadą niepogarszania sytuacji wierzycieli i obowiązkiem zapewnienia wewnętrznych źródeł pokrycia kosztów przymusowej restrukturyzacji. Spełniany jest przez fundusze własne i zobowiązania podporządkowane w postaci dłużnych instrumentów, które powinny być nabywane przez klientów profesjonalnych, co oznacza, że nie będą kierowane do inwestorów detalicznych. Jednostkowa nominalna wartość instrumentu stanowiącego zobowiązanie zaliczone do MREL będzie wynosiła nie mniej niż 100000 euro. Mechanizm MREL przewiduje możliwość kalibracji wskaźnika według trzech różnych scenariuszy (od najmniej do najbardziej wymagającego).

Z perspektywy zdobytych doświadczeń wyraźnie można dostrzec złożoność oczekiwań i podejmowanych działań tak na szczeblu międzynarodowych, jak i lokalnych instytucji bezpieczeństwa finansowego wobec instytucji ważnych systemowo. Regulacje makroostrożnościowe znacznie zwiększyły wobec nich wymóg kapitałowy, ponad poziom wyznaczony zapisami dokumentu Bazylea III. To skupienie się na regulacjach makroostrożnościowych miało położyć kres zjawisku instytucji postrzeganych jako "zbyt duże aby upaść". Trudno jednak w tak niedługim czasie ich obowiązywania ocenić, jaka będzie skuteczność oddziaływania na SIFI w warunkach materializacji ryzyka systemowego. Ryzyka tego nie da się bowiem całkowicie wyeliminować, podobnie jak nie można określić rozmiarów kapitału finansowego koniecznego do zabezpieczenia jego skutków.

\section{Podsumowanie}

Przeprowadzona wielopłaszczyznowa i wielokierunkowa analiza nowego instrumentu regulacyjnego, jakim jest wprowadzona po globalnym kryzysie finansowym polityka makroostrożnościowa, pozwala na sformułowanie szeregu wniosków i towarzyszących im kontrowersji wobec głównego przedmiotu badawczego opracowania, którym są SIFI - finansowe instytucje ważne systemowo. Zauważyć należy, że złożona procedura wyznaczania ich listy na szczeblu globalnym i w państwach członkowskich Unii Europejskiej nie wyczerpuje problemu ryzyka systemowego, generowanego przez duże korporacje międzynarodowe, identyfikowane jako TBTF. Ryzyko systemowe bowiem może materializować się pod różnymi postaciami i powstawać poza regulowaną 
działalnością SIFI. Ponadto zmiany, które dokonały się w systemie nadzorczym UE, przyczyniły się wprawdzie do zintegrowania odpowiedzialności za politykę makroostrożnościową na szczeblu Europejskiej Rady ds. Ryzyka Systemowego (ESRB), ale sam mechanizm nadzorczy w Unii Europejskiej pozostaje zdecentralizowany. Znaczna jest bowiem odpowiedzialność za politykę makroostrożnościową organów krajowych. Rozbudowany system instytucji nadzoru makroostrożnościowego w UE może więc pogłębiać problemy związane $\mathrm{z}$ zachowaniem stabilności systemu finansowego zarówno poszczególnych państw członkowskich, jak też całej Unii Europejskiej. Dlatego przyjęte rozwiązania instytucjonalne, ale również zidentyfikowane w opracowaniu instrumenty polityki makroostrożnościowej można jedynie uznać za intensyfikujące dyscyplinę regulacyjną $\mathrm{w}$ unijnym systemie finansowym, ale niedające gwarancji jego pełnego bezpieczeństwa finansowego. Poddane natomiast regulacjom ostrożnościowym i procedurze nadzorczej w Unii Europejskiej G-SIB i inne instytucje ważne systemowo, poprzez odpowiadające im bufory kapitałowe i procedurę resolution, zwiększają zapotrzebowanie na kapitał finansowy. W ten sposób w płaszczyźnie badawczej powstaje kolejny problem związany z dostępem do zasobów rynku finansowego i kosztem ich pozyskiwania. Wszystkie wyeksponowane powyżej argumenty odnoszące się polityki makroostrożnościowej wydają się przemawiać na rzecz tezy o niskiej jej skuteczności w dyscyplinowaniu stabilizującej roli SIFIs w systemie finansowym gospodarki globalnej.

\section{Literatura}

Bańbuła P.: Polityka makroostrożnościowa: przesłanki, cele, instrumenty i wyzwania. Materiały i Studia, nr 298, NBP, Warszawa 2013.

Basel Committee on Banking Supervision: Global systemically important banks: assessment methodology and the additional loss absorbency requirement. Bank for International Settlements, November 2011.

Boyd J. H., Heitz A.: The Social Costs and Benefits of Too-Big-To-Fail Banks: A "Bounding" Exercise. Journal of Banking \& Finance, No. 68, 2016.

Darvas Z., Schoenmaker D., Véron N.: Reforms to the European Union financial supervisory and regulatory architecture and their implications for Asia. ADBI Working Paper Series, No. 615, November 2016.

De Larosière J. (ed.): The high-level group on financial supervision in the EU. Report. Brussels, 25 February 2009.

Dobrzańska A.: Makroostrożnościowy wymiar regulacji CRDIV/CRR. Bezpieczny Bank 1(58), 2015.

Dyrektywa Parlamentu Europejskiego i Rady 2013/36/UE z dnia 26 czerwca 2013 r. w sprawie warunków dopuszczenia instytucji kredytowych do działalności oraz nadzoru ostrożnościowego nad instytucjami kredytowymi i firmami inwestycyjnymi, zmieniającą dyrektywę 2002/87/WE i uchylająca dyrektywy 2006/48/WE oraz 2006/49/WE. (OJ L176) - Capital Requirements Directive IV, CRD IV, art. 131 ust. 5 CRD IV.

EBC: Raport roczny EBC $\mathrm{z}$ działalności nadzorczej 2018. Retrieved: https://www.bankingsupervision.europa.eu/press/publications/annualreport/html/ssm.ar2018 927cb99de4.pl.html\#toc1. Dostęp: 15.04.2020.

ESRB: Macroprudential policy beyond banking: an ESRB strategy paper. July 2016. Retrieved: https://www.esrb.europa.eu/pub/pdf/reports/20160718_strategy_paper_beyond_banking.en.pdf. Dostęp: 15.04.2020. 
ESRB: Flagship Report on Macroprudential Policy in the Banking Sector. 2014. Retrieved: https://www.esrb.europa.eu/pub/pdf/other/140303_flagship_report.pdf. Dostęp: 15.04.2020.

European Banking Authority: Consultation Paper. Draft Regulatory Technical Standards on criteria for determining the minimum requirement for own funds and eligible liabilities under Directive 2014/59/EU. 28 November 2014, EBA/CP/2014/41.

Herring R., Carmassi J.: The structure of Cross-Sector Financial Supervision. Financial Markets, Institutions and Instruments, $\mathrm{nr}$ 1, 2008.

International Monetary Fund: Key aspects of macroprudential policy. June 10, 2013. Retrieved: https://www.imf.org/external/np/pp/eng/2013/061013b.pdf. Dostęp: 15.04.2020.

Nocoń A.: System reagowania współczesnych banków centralnych na niestabilność sektora bankowego. Difin, Warszawa 2016.

Olszak M.: Zintegrowany nadzór finansowy a ryzyko instytucji finansowych., [W:] T. Czerwińska, K. Jajuga (red.), Ryzyko instytucji finansowych. Współczesne trendy i wyzwania. Wydawnictwo C.H. Beck, Warszawa 2016.

Pyka I., Nocoń A., Cichorska J.: Nowy ład regulacyjny w sektorze bankowym Unii Europejskiej. CeDeWu, Warszawa 2019.

Rozporządzenie delegowane Komisji (UE) 2016/1608 z dnia 17 maja 2016 r. zmieniające rozporządzenie delegowane (UE) $\mathrm{nr} 1222 / 2014 \mathrm{w}$ odniesieniu do regulacyjnych standardów technicznych dotyczących określenia metody identyfikacji globalnych instytucji o znaczeniu systemowym oraz definiowania podkategorii globalnych instytucji o znaczeniu systemowym (tekst mający znaczenie dla EOG). Dz.Urz. UE nr L 240/1.

Rozporządzenie delegowane Komisji (UE) nr 1222/2014 z dnia 8 października 2014 r. uzupełniające dyrektywę Parlamentu Europejskiego i Rady 2013/36/UE w odniesieniu do regulacyjnych standardów technicznych dotyczących określenia metody identyfikacji globalnych instytucji o znaczeniu systemowym oraz definiowania podkategorii globalnych instytucji o znaczeniu systemowym. Dz. Urz. UE L 330/27 z dnia 15.11.2014 r.

Rozporządzenie Parlamentu Europejskiego i Rady (UE) nr 1092/2010 z dnia 24 listopada 2010 r. w sprawie unijnego nadzoru makroostrożnościowego nad systemem finansowym i ustanowienia Europejskiej Rady ds. Ryzyka Systemowego. Dz. Urz. UE L 331/1 z dnia 15.12.2010 r.

Schiavo G. L., Türk A.: The Institutional Architecture of EU Financial Regulation: The Case of the European Supervisory Authorities in the Aftermath of the European Crisis. [W:] L. Talani (eds.), Europe in Crisis. Palgrave Macmillan, London 2016.

\begin{abstract}
The macroprudential policy implemented due to the Basel regulations after the global financial crisis has a preventive nature, although it covers a number of institutional and instrumental solutions aimed at preventing the materialisation of systemic risk. The analysis of these solutions has been linked in the article with their orientation on financial systemically important institutions (SIFIs), operating in the European Union. It is indicated that institutional and instrumental solutions, implemented through the macroprudential policy, significantly increase regulatory discipline in the financial system of the modern economy; however they are not always transparent and their effectiveness is limited, due to the nature of systemic risk. Regulatory dispersion in the European Union is also observed in relation to systemically important financial institutions. It strengthens the arguments in favor of the idea that macroprudential policy has low effectiveness in disciplining the stabilizing role of SIFIs in the financial system of the global economy.
\end{abstract}

Keywords: macroprudential policy, systemically important financial institutions, capital buffers, MREL, TLAC

JEL Codes: G21, G28 
Informacje o autorach:

Prof. zw. dr hab. Irena Pyka

Uniwersytet Ekonomiczny w Katowicach

ul. 1 Maja 50, Katowice, Polska

e-mail: irena.pyka@ue.katowice.pl

ORCID: 0000-0001-5524-3550

dr Aleksandra Nocoń

Uniwersytet Ekonomiczny w Katowicach

ul. 1 Maja 50, Katowice, Polska

e-mail: aleksandra.nocon@ue.katowice.pl

ORCID: 0000-0003-3250-2382 